\title{
JAPÁN TÁRSADALMI REFLEXIÓK A BIZTONSÁGPOLITIKAI KIHÍVÁSOKRA
}

\section{JAPANESE SOCIAL REFLEXIONS ON SECURITY CHALLENGES}

\author{
Hidasi Judit \\ japanológus, professor emerita, Budapesti Gazdasági Egyetem \\ hidasi.judit@uni-bge.hu
}

\begin{abstract}
ÖSSZEFOGLALÁS
Japán a természeti katasztrófáknak legjobban kitett országok közé tartozik, a szigetországban gyakoriak a földrengések, cunamik és egyéb csapások. A japán társadalom az idők folyamán megtanult együtt élni a különböző fenyegetésekkel, és az emberek és az intézmények alaposan felkészültek a veszélyhelyzetekre. Az állam, a helyi közösségek és az egyének viselkedését is jól kidolgozott protokollok szabályozzák katasztrófák esetén. A 2011-es hármas csapás azonban megrengette az ország önbizalmát, és az utóbbi években a fenyegető természeti csapások mellett a geopolitikai helyzetből adódó biztonsági kihívásokra is választ kell találni. A tokiói olimpia sokat segíthet a japánok önmagukba vetett hitének helyreállításában.
\end{abstract}

\begin{abstract}
Japan is among the countries that most frequently face natural disasters; the country regularly experiences earthquakes, tsunamis and other calamities. Japanese society, through the ages, has already learnt to deal with the catastrophes of different types, and people and institutions are well prepared for difficult situations. In cases of emergency, the conduct of the state, of local communities, as well as of individuals is controlled by detailed protocols. The triple disaster of 2011, however, dealt a huge blow to the self-confidence of Japan; moreover, in recent years, apart from natural disasters, the country needs to find answers to security challenges posed by the country's geopolitical position. The Olympic Games in Tokyo can contribute to the restoration of the Japanese people's faith in themselves.
\end{abstract}

Kulcsszavak: Japán, biztonság, katasztrófaelhárítás, katasztrófamegelőzés

Keywords: Japan, security, disaster relief, disaster protection 


\section{A KONTEXTUS}

Japán földrajzi adottságainál fogva - szigetek ezrei által alkotott ország - és elhelyezkedése miatt - egy hatalmas geológiai törésvonal mentén fekszik a Csendes-óceánban - számos veszélynek, természeti csapásnak, bizonytalanságnak (földrengés, cunami, tájfun) van kitéve. Ezekkel a feltételekkel az ország lakói az évszázadok során megtanultak úgy-ahogy sikeresen együtt élni, és a kihívásokat a lehető legjobb hatékonysággal kezelni. A naprakész felkészülést a veszélyekre képzéssel, tréningekkel, felvilágosító kampányokkal és rendezvényekkel támogatja az oktatási rendszer, a média és a civil szerveződések hálózata. Mindehhez járul az utóbbi években egyre erősödő regionális geopolitikai feszültség, aminek a kezelésére történnek ugyan különféle szintü felkészítési intézkedések, de kérdés, hogy a lakosság kitartása, ébersége és türelme meddig terjed. E rövid tanulmány a társadalompszichológiai háttér kontextusában néhány konkrét példán keresztül mutatja be a lakossági reflexiókat.

\section{A TERMÉSZETI KATASZTRÓFÁK KEZELÉSE JAPÁNBAN}

Japán lakossága a természeti katasztrófák - legyen az földrengés, tájfun vagy szökőár - időnkénti bekövetkezéséhez úgymond szokva van. Egy ösi japán mondás - „, földrengés, mennydörgés, tüz és az öreg (apa)” (jishin, kaminari, kaji, oyaji) - találóan figyelmeztet a mindennapokban ránk leselkedő veszélyforrásokra. A világon előforduló földrengések húsz százaléka Japánt sújtja, ami az ország tektonikailag érzékeny földrajzi elhelyezkedésének tudható be. Évente kb. kétezer rengés éri az országot, amelyek közül néhányat élénken őriz a történeti emlékezet. Az 1923. szeptember 1-jén bekövetkezett kantói földrengés (Tokió és Jokohama központtal) olyan hatalmas pusztítást okozott (Kiss, 2017), hogy komolyan fontolgatták a főváros áthelyezését. De végül is inkább sok beton, acél, üveg és égésbiztos anyag alkalmazásával újjáépítették Tokiót, ami 1935-re „világvárossá” nőtte ki magát. 1960 óta a csapás emlékére szeptember elseje úgynevezett „országos katasztrófamegelőzési nap”. Emlékezetes volt az 1995-ben bekövetkezett Hansin-Avadzsi-földrengés (Kóbe központtal, a Csendes-óceán peremvidékén délebbre), aminek az évfordulóján 1996 óta minden január 17-ét a „katasztrófaelhárító önkéntesek napjaként” tartanak számon. 2011-ben Szendai megyeszékhellyel a központban Tokiótól 300 km-re északra a Tóhoku-vidéket érte hatalmas pusztítás: földrengés, cunami és az atomerömüben bekövetkezett ipari balesetet követő nukleáris szivárgás. Ennek emlékére november 5-ét a „cunami-védekezés napjaként" deklarálták nemzeti emlékezeti nappá. Japán és külföldi tudósok nem rejtik véka alá azt sem, hogy 70\%-os esélyt jósolnak egy, a közeli jövőben bekövetkező pusztító földrengésnek (Tokió központtal). 
Ezek után felmerül a kérdés, hogy emberileg mit lehet tenni a megelózés és a felkészülés érdekében? Az intézkedések kiterjedtek és sokfélék, és a közigazgatástól kezdve a közintézményeken át a lakossági közösségeken keresztül egészen az egyénekig számos utasítást és feladatot foglalnak magukban. Ezek egy része a tájékoztatásra, más része a felkészítésre, egy csoportja a megelőzésre, és végül egy tucatnyi a kárkezelés szintjére irányul. Ezek közül néhányat kiemelve érzékelhetjük, hogy prioritást élvez a tudatosság, az éberség és az adott protokoll szerinti cselekvési rend kialakítása a lakosságban. A japán szabálykövető nép - mindenkinek jól felfogott érdeke, hogy fegyelmezetten és szervezetten kövesse az eljárásrendet. Mindez nagyon hasznos és hatékony mindaddig, amíg a katasztrófa a kezelhetőség határain belül marad.

Példák a felkészülésre:

- Minden iskolában az első tanítási napon az eligazítás része a földrengésmegelözési gyakorlat, amelyet aztán a tanév során még több alkalom követ. Ezek során egy szimulált katasztrófahelyzetben gyakoroltatják a teendőket. A japán óvodákban és iskolákban már kiskortól fogva tanítják a gyerekeket a vészhelyzetekben követendő magatartásra - ilyen például a fej védelme, az asztal-, illetve padlap alá bújás, a mozgó tárgyak elleni védelem stb.

- A háztartásokban - rendszerint a bejárat közelében - kerül elhelyezésre az a kis „menekülö-készenléti csomag”, külön-külön a család valamennyi tagja számára, amely számos hasznos tárgyat, eszközt (zseblámpa, pokróc, meleg ruha, száraz étel, víz, gyógyszer, aprópénz stb.) tartalmaz arra az esetre, ha a szabadba kéne menekülni.

- A helyi közösségek gondoskodnak úgynevezett evakuációs pontok kialakításáról - sportpályák, iskolák udvarai, parkok stb. -, ahová vészhelyzet esetén a közösség tagjai menekülhetnek mindaddig, amíg utasítás nem érkezik a további teendőkről.

- A helyi közösségek, vállalatok, cégek rendszeresen szerveznek szimulációs gyakorlatokat: belső termi gyakorlatokat (asztal alá bebújni, fejet védeni, asztallábba kapaszkodni), tűzoltási gyakorlatokat, emeletről lesikló gyakorlatokat.

- A Japánba érkező külföldit is rendszerint az első tudnivalók között tájékoztatják ezekröl a szabályokról, legyen az munkahely, kollégium, egyetemi kampusz vagy bérlakás.

Fontos és életmentő lehet a katasztrófa-elörejelzési technológiák folyamatos fejlesztése. Azt a tudósok rendszerint jó találati hatékonysággal meg tudják jósolni, hogy mekkora erősségü földrengés várható, sőt azt is, hogy nagyjából hol. Azt, hogy mikor - sajnos még nem. Jelenleg a tudomány ott tart, hogy a már elindult, azaz közeledő földrengést 80 másodperccel a bekövetkezés elött jelzi a riasztórendszer. Jó esetben ez elegendő lehet a gáztűzhelyek kikapcso- 
lására, az üvegablakoktól való ellépésre, fedezékbe bújásra. A 2011. március 11-én történt katasztrófa idején 27 Sinkanszen-szerelvény volt robogásban (250 km/óra) a 9,1-es erősségü földrengés bekövetkezését megelőző percekben, de az előrejelző szenzorok hatásos figyelmeztetésének köszönhetően másodpercekkel előbb valamennyi leállt. 1952 óta müködik cunami-elörejelző országos szolgálat háromszáz szenzor müködtetésével, amelyek a szeizmikus mozgásokat mérik és jelzik, ezekből nyolcvan víz alatti. Ezek az eszközök közlik a hullámmagasságot, sebességet, előfordulási helyet és a becsült partra érési időt. A cunami-gátak és cunami-védőfalak felhúzása a tengerparti községekben ugyancsak védelmet nyújthat, persze csak addig, amíg ezek magasságát és ellenálló képességét jól becsülik meg. A 2011-es hármas Tóhoku-katasztrófa súlyosságának egyik oka az lehetett, hogy a lehetséges cunami nagyságát nem megfelelőn becsülték fel, és a védőgátak nem bizonyultak kellően magasnak és erősnek. 2011. március 11-én a - történelmi léptékben is rendkívül erösnek minősülő, a Richter-skála szerint 9,1-es fokozatú - földrengést magát a fukusimai erőmü ugyanis sértetlenül „túlélte”, de nem így az azt követő példátlanul hatalmas cunamit, amelynek az ereje iszonyatos rombolást végzett, és végül az atomerőmü sérülése miatt nukleáris katasztrófához vezetett. A következmények ismertek: az eleinte kezelhetőnek vélt sérülések az erőmüben olyan horderejüeknek bizonyultak, hogy nemcsak a szigetországot, hanem a tágabb környezetet és az ökovilágot is maradandó módon károsították. A nukleáris szivárgás hosszú távú hatásai egyelőre messze nem feltártak, és a folyamat megnyugtató módon még nem zárult le.

A japán hírközlésben - elsősorban a televízióban - egy kidolgozott kódrendszer figyelmeztet a veszélyre, illetve, ha lehet, akkor már a veszély közeledtére is. Nemcsak az éppen aktuálisan zajló adás alatt jelenik meg a képernyő szegélyén írott formában (vizuálisan) a vészre való figyelmeztetés, hanem egy sajátos kis éles csengö hang (audiálisan) is felhívja a figyelmet arra, hogy kéretik a képernyőre tekinteni - tehát a képernyő előtt ülőkön kívül hangzó módon a lakás, iroda vagy vendéglő távolabbi sarkában tevékenykedőket is figyelmeztetik a rendkívüli hírre. Ilyenkor tanácsos minden más tevékenységet megszakítva a legközelebbi készülékre tekinteni, ahol egy fel-felvillanó híradássor tájékoztat a részletekről. A lakosság az eseményeket és a fejleményeket tehát rendszerint élőben követi a televízión. Szükség esetén sor kerülhet az adás megszakítására is - amikor is televíziós hírolvasók tájékoztatnak a vészhelyzetről, illetve teendőkröl: figyelmeztetnek a közlekedésben várható késésekről, járatkimaradásokról, menekülési útvonalakról stb.

Az építési technológiák terén is óriási fejlesztéseknek lehetünk tanúi. 1981ben szigorodott az építési engedélyekre vonatkozó szabályozás - kvázi „földrengésbiztos", acéllal megerősített betonoszlopok földbe helyezését írták elő -, különösen középületeknél. Ezeket a technológiákat folyamatosan fejlesztik, tö- 
kéletesítik. Itt is felmerül ugyanakkor az a kétely, hogy egy valóban hatalmas földrengés esetén ezek a megoldások elegendőek-e az épületek összeomlásának a megelőzésére.

Egy-egy katasztrófa bekövetkezését követően a lakosság példamutató fegyelmezettséggel és munkabírással haladéktalanul a romok eltakarításához lát: rendszerint hihetetlen gyorsasággal és hatékonysággal építik újjá a környezetet és lakóhelyeiket. Önsajnálat és panaszkodás nélkül teremtik újjá saját élö- és munkahelyeiket, és a külső megfigyelő számára szinte felfoghatatlan hatékonysággal üzemelik be újra saját világukat. Így történt ez a 2011 márciusában bekövetkezett hármas természeti katasztrófát követően is. Ez a katasztrófa - a közvetlenül jelentkező hatalmas emberi, anyagi, infrastrukturális és környezeti károkon felül (a Sinkanszen-szuperexpressz 675 kilométeres keleti szakasza ezerkétszáz ponton sérült meg!) - számos olyan folyamatot indított el Japánban és a világban is, amelyeknek a hatásai messze túlmutatnak magán a baleseten.

Japán lakosságát - annak ellenére, hogy természeti katasztrófákon szocializálódtak, a természeti katasztrófákkal együtt élnek, és hogy a természeti katasztrófák kezelésében a világ talán legedzettebb népe - a fukusimai katasztrófasorozat igen mélyen megrázta. Ezt a világ kevéssé érzékelte - hiszen a megrendítő károk és pusztítások látványos jelenetei mellett a híradások egy nagyon fegyelmezett, érzelmeit kordában tartó lakosság képét közvetítették. A nagyvilágban ezt sokan értetlenkedéssel fogadták: az érzelemnyilvánításnak ezt a lefojtottságát már-már természetellenesnek ítélték. Az érzelmek és indulatok szabad kifejezése sohasem volt a japán kultúra sajátja - de a mélyben az egyéni tragédiák ugyanúgy meggyötrik az elszenvedőket, mint bárhol másutt a világon. Az, hogy mennyit és hogyan kell kommunikálni (egzaktság, részletesség, implikáció stb.) ahhoz, hogy a társak értsék, és úgy értsék, ahogy azt az üzenet küldője szeretné, kultúránként erősen eltér. A japán mentális programozottság itt két alapelvre épít. Az egyik az, hogy másokat saját tragédiánkkal, fájdalmunkkal nem terhelhetünk - ezért nem engedhetünk szabad utat érzelmeinknek, fájdalmunk kifejezésének. A másik az a szamuráj viselkedési kódot is alapjaiban átható elvárás, hogy érzelmeinken tudjunk uralkodni: ez az érettség, a fegyelem, az önerö jellegzetes megnyilvánulása. Japánban az őszinte kibeszélés, megbeszélés és átbeszélés helyett - ami az esetleges társadalmi vagy személyközi konfliktusok egyfajta oldását és terápiáját is jelenthetné - nagyobb hangsúlyt kap az elvárásoknak megfelelő fegyelmezett viselkedés. A japán értékrendben a harmónia az emberi érintkezés egyik alapvető rendezőelve, amely mindenekelött a nyílt konfrontálódás elkerülésében manifesztálódik. Ezért nem láthattunk egymásra mutogató és kiabáló embereket, kétségbeesett arcokat és a természetet vagy az embertársakat vádoló lakosokat.

Hatalmas csalódást jelentett a japán társadalmi tudat számára az, hogy a fejlett japán technológia (Vogel, 1979; Morita, 1986) kudarcot vallott. Ez nemcsak 
az őket ért kár miatt érintette fájdalmasan őket, hanem azért is, mert egyfajta presztízsveszteségként élték meg: a világ technológiailag legfejlettebbnek tudott országának nem sikerült felülemelkednie ezen a baleseten. A keleti kultúrák némelyikében oly nagy szerepet játszó ,szégyen”-faktor lépett itt müködésbe. Ha pedig valami szégyenteljes, akkor lehetóség szerint azt rejtegetni kell - kommunikatíve is (Hidasi, 2017). Ez nagyfokú bizalomdeficithez vezetett mind a japán kormány, mind pedig a szakmai hatóságok kommunikációja irányában - ami az amúgy is elgyötört lakosság bizonytalanságérzetét tovább fokozta.

\section{A KÜLSŐ FENYEGETETTSÉG ELLENI FELKÉSZÜLÉS}

A lakosságot és a közvéleményt az utóbbi években nemcsak a természeti katasztrófáktól való félelem tartja bizonytalanságban, hanem az országot érintő geopolitikai kihívások is: az amerikai támaszpontok áthelyezése Japánon belül (nemzeti és lokális érdekek ütközése az USA-val); az északi Kuril-szigetek sorsának perspektívái (japán és orosz érdekek ütközése); szigetviták (amelyek során Japán és Dél-Korea, valamint Japán és Kína közötti birtoklási érdekek ütköznek); és nem utolsósorban a katonai fenyegetettség Észak-Korea szomszédságában. Jelenleg biztonságpolitikai szempontból ennek az utóbbinak van a legérzékelhetőbb rezonanciája a japán lakosság körében.

A rendkívül bonyolult és összetett erőviszonyok és érdekszférák ütközésének és az észak-koreai fenyegetéseknek az elsődleges deklarált célpontja ugyan nem Japán, hanem az USA, de a japán szigetek és felségterületek felett időről időre átröppenő és a Csendes-óceánban landoló észak-koreai ballisztikus rakéták joggal tartják folyamatos rettegésben a lakosságot. A Time magazin egyik cikkében Charlie Campbell az alábbi nyilatkozatot idézi Phenjantól: „A (japán) szigetsor négy szigetét a dzsucse nukleáris bombájának a tengerbe kellene süllyesztenie... Japánnak nem kell többé mellettünk léteznie" (Campbell, 2017). Az ilyen és hasonló kijelentések - legyenek bár „csak verbális” fenyegetések - érthető módon fokozzák a tanácstalanságot, és a lakosságot arra késztetik, hogy akár egy nukleáris támadás lehetőségét se hagyják figyelmen kívül.

Mint ismeretes, sem Japán, sem Dél-Korea nem nuklearizált ország, azaz az atomenergiát csak békés célokra fejlesztették és használták, katonai célokra nem. Azaz Japán katonailag nem készült fel egy esetleges külső támadás elhárítására. Ezt az 1947 óta érvényben lévő úgynevezett „,békealkotmány” nem is tenné lehetővé. Ennek 9. cikkelye kimondja, hogy a szigetország ,szárazföldi, tengeri és légi erőt, valamint egyéb hadi potenciált nem tart fönn”. A jelenlegi Japán Önvédelmi Erők (Self-Defense Forces) harcászati felhatalmazással nem rendelkeznek, és tevékenységük sokszor katasztrófaelhárításban merül ki. Noha a 9. cikkely módosításának gondolata konzervatív politikai körökben már számtalanszor fel- 
merült, de a lakosság és a közvélemény heves ellenállásába ütközik. Ők ugyanis abba az illúzióba kapaszkodnak, hogy amíg érvényben van a 9. cikkely, addig Japánban nem ütheti föl a fejét háború. A remilitarizációtól való félelmet ugyanakkor sokakban felülírja az az aggodalom, hogy vajon helyesen jár-e el Japán, ha nem cselekszik. A feszültség fokozódásával egyenes arányban a lakosság is kénytelen belátni, hogy jelenleg Japánnak sem alkotmányos, sem katonai értelemben nincs lehetősége „cselekedni”. Abe Sinzó kormányf” feltett szándéka - hivatkozva a kiélesedett nemzetközi helyzetre - 2020-ra átírni és módosítani az 1947-es „békealkotmányt”. Ehhez azonban kétharmados parlamenti többség szükséges, majd ezt megerösítendő egy referendum.

A japán médiában kiemelt helyen foglalkoznak a Dél-Koreában tartózkodó japán állampolgárok hazatelepítésére vonatkozó előkészületek ügyével is. Becslések szerint mintegy 60 ezer japán állampolgár tartózkodik Dél-Koreában: közülük 38 ezer fő hosszú távú rezidens, 19 ezer fő rövid távú rezidens, illetve turista. Vészhelyzet esetén ezeknek a japánoknak a Japánba menekítésére különféle szcenáriók kerültek kidolgozásra. Noha a két Korea közötti feszültség enyhülése ezeket az előkészületeket okafogyottá teheti, de kérdés, hogy meddig tart a békülékenyebb légkör.

Japánon belül a koreai rakéta- és esetleges nukleáris támadások esetére is az úgynevezett J-Alert figyelmeztető és elörejelző rendszert állították rendbe, amely köztéri szirénák sivító hangjával figyelmeztet a veszélyre. A médiafigyelmeztetések rendszerét a természeti katasztrófa- és földrengésriadóktól jól elkülönített módon szervezték meg: a tévéképernyő feketére vált, és fehér betúkkel írja ki a légitámadásra való figyelmeztetést; az okostelefonokon speciális hangjelzések szólalnak meg. A kijelölt menekülési pontok mellett gondoskodni kellett megfelelő föld alatti búvóhelyek kialakításáról is. Míg a földmozgásoknál a rengő épületekböl sokak számára a szabadba történő menekülés jelent biztonságot, a légitámadások elleni felkészülés során a közösségi gyakorlatok a bunkerekbe, fedezékekbe történő bemenekülést szimulálják.

A légvédelmi gyakorlatok megyei, járási, városi, körzeti beosztásban rendszeressé váltak. A saját testi épséget védő és túlélési felszerelések iránti kereslet megemelkedése mellett látványos igény jelentkezett „bombabiztos konténerek” és föld alatti bunkerek iránt.

Mindezekből az akciókból jól érzékelhető az a törekvés, hogy a lakosságot és a társadalmat ne csak infrastrukturálisan, technikailag és szervezetileg készítsék fel, hanem lelkileg is. Egy japán közmondás találóan fogalmazza meg: „ha a holnapról szólsz, az egerek kuncognak a padláson" (ashita no koto wo iu to tenjou no nezumi ga warau) - vagyis a holnap, a jövő kiszámíthatatlan. De jobb félni, mint megijedni, s ami emberileg lehetséges, arra a japánok felkészülnek. Japán tipikusan „fönixkultúra” - reménytelen helyzetekből is képes talpra állni (Muraközy, 2016). 


\section{ZÁRÓ GONDOLATOK}

S hogy melyek azok a szabályok és ajánlások, amelyek hatékonyan segíthetik a lakosság felkészülését az előre nem látható eseményekre? Az alábbiakat érdemes kiemelni:

- Mindenki legyen képes öngondoskodásra, s ismerje a cselekvési láncokat.

- A katasztrófák megelözése és az információk terjesztése stádiumában minden lehetséges kommunikációs csatornát érdemes mozgósítani, igénybe véve a tömegkommunikációs eszközök gazdag tárházát.

- Az önellátást és gondoskodást követően törekedni kell a közösség segítésére.

- Katasztrófa bekövetkezése esetén nem elegendő a lakosság megnyugtatása, a pánik megelózése végett az indulatok lehủtése - hiteles tájékoztatásra van igény:

○ a túl kevés vagy hézagos információátadás teret ad a spekulációknak;

○ az információ helyes időbeli ütemezése (nem túl korán, nem túl későn) javíthatja az információ hatékonyságát.

Igazi nagy kihívás lesz a 2020. évi nyári olimpia, hivatalos nevén a XXXII. Nyári Olimpiai Játékok megrendezése Tokióban. Noha Tokió már rendezett korábban is (1964) olimpiát, amelynek a sikere nagyban hozzájárult a japán imázs erősítéséhez, de ennek a 2020-as rendezési jognak a jelentősége társadalom-lélektani szempontból felülmúlhatatlan: egy bizalmában csalódott, erejében megingott és társadalmilag megrendült ország előtt ismét olyan cél lebeg, amely hatalmas áldozatok és erőfeszítések árán ugyan, de mégis katalizátorként hathat a társadalmi összefogás, a társadalmi együttműködés és a nemzeti önbecsülés helyreállítása területén. A japánok úgy érzik, hogy a világ szemében visszanyerték a tekintélyüket, az ország képességeibe és lehetőségeibe vetett bizalmat, aminek maximálisan meg is kívánnak felelni - a felkészülés rengeteg munkahelyet teremt, felelösséggel jár, és tömegeket tart izgalomban. Az olimpia helyszíneként kijelölt Tokió ugyanakkor gigászi feladatra vállalkozott: a japán kormány és a nép az olimpiai játékokra mint az országimázs-építés egyik felülmúlhatatlan eszközére tekint. A kormány egyik kevésbé hangoztatott, azonban mélyen nagyon is meglévő várakozása és reménye pedig a nemzeti identitásra, a nemzeti kohézió erősödésére gyakorolt pozitív hatásra irányul.

\section{IRODALOM}

Campbell, C. (2017): 'This Is All We Can Do': How the Japanese Are Preparing for a North Korean Nuclear Attack. The Time, 20 Sept. 2017. http://time.com/4949262/north-korea-japan-nuclear-missiles-drills/ 
Hidasi J. (2017): A válság kommunikációja - a kommunikáció válsága: A 2011-es hármas japán természeti katasztrófa kommunikációs tanulságai. In: Borgulya Á. - Konczosné Szombathelyi M. (szerk.): Vállalati kommunikációmenedzsment: tanulmánykötet. Budapest: L’Harmattan Kiadó-KRE, 17-29.

Kingston, J. (2004): Japan's Quiet Transformation: Social Change and Civil Society in the Twenty-first Century. London: Routledge Curzon

Kiss S. (2017): Japán vonzásában: Magyarok, akik szerették Japánt. Budapest: Holnap Kiadó

Morita, A. (1986): Made in Japan. Tokyo: Asahi Shinbunsha

Muraközy L. (2016): A japán rejtély: Útteremtö csodák és végzetes zsákutcák. Budapest: Akadémiai Kiadó

Vogel, E. F. (1979): Japan as No.1. Lessons for America. Cambridge, MS: Harvard University Press 